\title{
Outlining the Challenges of COVID-19 Pandemic on Africa's Maritime Industry: the Case of Marine and Seafaring Professionals
}

Anthony Djaba Sackey ( $\sim$ deckcadetsackey09@gmail.com )

DNV GL Oil and Gas/ Grassfield Maritime Consultants, Nigeria/ RROC Industrial Limited, Accra, Ghana https://orcid.org/0000-0001-5032-1089

Bertrand Tchouangeup

DNV GL oil and Gas/ Grassfield Maritime Consultants

Bernard Lomotey

DNV Maritime/ Ben Marine Services

Benjamin Lantei Lamptey

University of Leeds

Raphael Ofosu-Dua Lee

DNV GL Oil and Gas/ Grassfield Maritime Consultants, Nigeria, RROC Industrial

ABIGAIL Dede Sackey

German Institute of Technology

Joseph Elorm Segbefia

GISMA Business School

Abraham Akwertey Teye

Ghana Armed Forces

Richmond Kennedy Quarcoo

Plastic Punch NGO

John Bansah

MEGA food Industries

Christabel Ewedji

Ant Marine W.A Consulting Services

Ekow Eduhene Wood

Bernard Shulte Shipping Management

\section{Research Article}

Keywords: Covid-19 impact on crew mamanegemt, Health Crises on marine operation, Policies and Regulations in maritime, Maritime Operations and Pandemic, offshore operations in Africa

Posted Date: November 30th, 2021

DOl: https://doi.org/10.21203/rs.3.rs-978145/v1

License: (c) (1) This work is licensed under a Creative Commons Attribution 4.0 International License. Read Full License 


\section{Abstract}

Despite the 'Key Worker' status accorded seafarers in moments of demonstrable selflessness -ensuring, adequate supply of food, medicines, consumables like personal protective equipment (PPEs), and energy - there is a lack of genuine interest in their concerns, leading to various calls from major stakeholders such as the United Nations and International Maritime Organization. These calls associate- with various covid-19-related policies and regulations having a direct bearing on the ongoing crew change crises, maroon and overstay of contracts, poor mental health, rise in covid-19 infections and other unrelated illnesses among ship crew.

Thus, to what extent are non-traditional seafaring nations of Africa being impacted? The study examines these concerns by identifying and investigating implemented covid-19 policies and regulations and their impact on maritime operations and crew 'wellbeing;' the contingency measures and innovations aiding mitigate responses with minimal challenges to seafarers and marine professionals. The case study approach focuses on West Africa's maritime corridor, examining operations in Ghana, Ivory Coast, Liberia, Nigeria and Angola to a host of varied ports and offshore installations operations. Direct field observations, as well as questionnaires and interviews of expert or 'eye witness' account, deployed via phone calls, online social media and emails are carried out. The study finds MLC 2006 was not been complied with. Embarkation quarantine measures and testing implemented for offshore Ghana and Angola could not prevent the outbreak of cases onboard FPSO units respectively, though the process identified positive cases during quarantine. The stigma associated with positive cases amongst the crew were prevalent in the first six months of pandemic declaration. Of the survey conducted amongst 71 vessel crew, $32.14 \%$ were certain of having recorded Covid-19 positive cases on their various Jobsites, $91.06 \%$ showed support for IMO-led interventions against covid-19, 30\% complained of uncertainty spared by rumours as fueling poor mental health. However, only $19 \%$ willingly addressed issues of their proximity to covid-19. Vaccine inoculations upon commencing March 2021 remained low in the region amongst marine professionals. Mitigating measures implemented include increased internet and call access, and extensive boarding protocols.

In conclusion, lessons learnt within these periods of history going forward should inform the need for a comprehensively developed global emergency response contingency regulatory plan that identifies various potential threats, establishes adequate measures and make adjustment for review and amendments - to be instated only in times of global emergencies.

\subsection{Introduction}

Annually, international trade is said to be composed of 80 per cent in value of maritime trade contribution (two-third of trade volume), which are led by both national and private seaports (UNCTAD, 2019; Sackey et al., 2021), before the maritime industry, thanks to the men and women who dedicate their lives to the seafaring trade (included are all maritime professional); were forced to maintain operations under very difficult, stringent, unhealthy and odd circumstance as a result of the global emergency towards ensuring that the fundamental sanctity of human life sustained with the much-needed supplies of food, energy and health care products (Sackey et al., 2021). According to BIMCO, (2015) the global supply of seafarers was estimated at 1,647,500 seafarers, of which 774,000 are trained officers and 873,500 are trained ratings compared to $1,371,000$ with 624,000 officers and 747,000 ratings respectively estimated five years earlier. Thus with a shortage in supply estimated at 102,500, the demand forecast for 2020 and 2025 stood at $11.7 \%$ and $18.3 \%$ concurrently. This potential market demand since the last decade has become a commodity of interest to the non-traditional seafaring nations and regions across the world, particularly among African nations who seek to exploit the advantages of the global labour supply shortfalls into training prospective maritime professionals and seafarers ${ }^{[1]}$ at various levels of competencies for foreign exchange earnings. Though the end of the year 2019 in the global maritime industry set forth with great optimism (Sackey et al., 2021; Lee Hong Liang, 2020)-thus in marking the new decade, the serious challenges of compliance to newer environmental regulations, need to maintain and increase technical innovation in the ship and engine design, among other global concerns, was compounded by the World Health Organization's (WHO) March 11 declaration (Sackey et al., 2021; Seatrade-maritime.com, 2020) of the coronavirus pandemic.

According to Sackey et al. (2021), the emergency declaration resulted in initial spontaneous series of health-inspired restrictive interventions and policies -a reaction across the nations of the world that naturally can be described as an 'upfront' to migrations. Thus one of the most fundamental pillars of globalization, all done towards averting potential worldwide health catastrophe.

As large as the African continent appear, thus constituted by 54 nation-states with a population of over a 1.26 billion as of 2016 (Wordometer, 2020 ), currently estimated at 1,340,598,000 in 2019, of which the sub-Saharan Africa region constitutes $1,094,366,000$. These countries are reliant on international trade under the health crisis with the mode of spread of disease mitigated via the implementation of foreign and localised travel restrictions, which has seen various national borders closed. Ghana as a case in point was as of March 302020 closed to international travellers (Sackey et al. 2021; www.garda.com, 2020). Fortunately, or rather unfortunate for marine professionals and seafarers engaged in maritime operations within Ghana like other African nations during the early stages of the pandemic, were face with (Sackey et al. 2021) extreme health scrutiny and 'private invasion.' According to Sackey et al. (2021), the seaport of Tema Port and the Kotoka International Airport (KIA) within the nation's capital were subjected to surveillance as well as internal and external travel restrictions. The Takoradi seaport located within the Western region serving as an international shipping route and a hub for offshore oil and gas operations in Ghana was however not spared in the external travel restrictions. Operations of ships at these seaports were restricted to ships already berthed, those awaiting berth allocations while in anchorages, and those en route offshore locations under the government's policy guidelines --subject to the rapidly changing situational timeline and data. As many seafarers across the world, particularly, of the fractional population within Africa continue to face numerous difficulties, largely spared by the covid-19 pandemic. The consequences of rapid job losses, to various health problems, skyrocketing cost of living, midway contract forfeitures, overstay of contracts, unpaid wages for times on board, as well as forced or unconsented reduction in wages under the guise of covid-19, cannot be overstated as a bad streak of seafarer business. Regardless of the times, seafarers (those onboard ships and those at home in search of vessels, particularly African seafarers) are required to pay the exact cost for their STCW 95:2010 (as amended) documentations and training renewals without any financial support or any form of covid-19 relief. Sackey et al., suggest seafarers and marine professionals in their daily duty are not alien to absorbing all forms of occupational risk and therefore, understood the risk they faced with Covid-19 health crises in terms of risk to their health while on Jobsite.

Page 2/18 
Hence, the study examines the impact of the crises on these identified objectives: thus, identify and investigate some of the current policy implementations and practices regulating the seafarers amid covid-19; develop an understanding of key aspects of the maritime operations and seafarer 'wellbeing' impacted by the covid-19 crises; and determine some of the best contingency measures and innovations as the most appropriate mitigating response. Therefore, upon successful examination of the seafarers' concerns amidst the pandemic, a resolution in this study should help counter future crises and consequential fallouts for the maritime industry. The significance of this study is because finding will lay bare the real challenges experienced in the African maritime industry while helping inform policies decisions and regulations in the future. It will also espouse the best approach at balancing regulations and welfare of maritime professionals (thus seafarers' 'well-being') while helping sustain high integrity operations in a world emergency.

[1] The term seafarers, is used generically to refer strictly restricted to the traditional role a ship's crew memer or individuals trained and certified as competent to discharge a responsibility at sea. Therefore, the term marine professional is not limited to only seafarers but individual with non-traditional roles on ships but may work onboard for a period. Hence, this term may be used interchangeably as it ascribe to the larger pool of diverse careers of marine personnel whose duties also encompass ship site or boarding marine vessel for shorter or longer durations. E.g., are subsea engineers and marine surveyors?

\subsection{Literature Review}

\subsection{Overview of COVID-19 Virus: the Maritime Industry's Recount of the Health Crises}

The March 11 2020, declaration of pandemic scale virus worldwide set in motion a series of localised and international restrictions- the IMO SecretaryGeneral (S.G.) per Circular Letter No.4204/Add.14/Rev.1 5 of October 2020 insisted, forced a huge number of seafarers into an indefinitely stay at sea (Sackey et al, 2021). Essentially, the situation buttresses Thetius' (2020) claim which Sackey et al. (2021) affirmed, that the new Coronavirus was "causing significant problems for the maritime industry, with volatile supply and demand, port closures, and difficulties with crew changes." Therefore, we examine the generic features of this virus, the current state of the global pandemic and health crises, and how impacting on maritime operations over the period of crises.

According to WHO (2020); the John Hopkins University, the John Hopkins Hospital, Zhou et al., (2020) and the John Hopkins Health System (2020), the newly identified SARS-COV-2 (also widely referred to as Covid-19) is a type of virus that emerged from China in December 2019 resulting in the worldwide pandemic of respiratory infections. Listed symptoms to included "coughs, chills or fever, shortness of breath or difficulty in breathing, muscle or body aches, sore throat, loss in taste or smell, diarrhoea, headache, fatigue, nausea or vomiting and congestion or running nose" (as cited by Sackey et al. (2021). Thus, infections are said to be severe -leading to eventual death in some cases and the mode of spread is from person to person, whereas diagnoses are solely through laboratory testing. According to WHO (2020), of the number who may develop symptoms, close to 80 per cent recover naturally from the disease without hospital treatment. 15 per cent however become seriously ill and may require oxygen whereas the remaining 5 per cent become critically ill and may need intensive care.

Given that anyone can fall ill with Covid-19, individuals within the age 60 years plus, as well as people with chronic underlying medical problems such as high blood pressure, heart and lung problems, diabetes, obesity or cancer, remain at higher risk of becoming seriously ill. It is however unclear, what the long-term effect of covid-19 are and thus remains the focus of many clinical researchers including those within the WHO (2020).

While the global cumulative infection rate stood at 40, 118,333 as of October 18 2020, and the Covid-19 death count at 1,114,749 (WHO, 2020), fastforwarding to July 162021 , the global count of total infections stands at 188,655,968 confirmed cases, including 4,067,517 deaths. Africa's share of confirmed infections at the same time stood at 4,531,636 including 106,074 infection deaths (WHO, 2021). With daily updates (Sackey et al, 2021) suggesting a continuous rise despite progress made, John Hopkins et al. (2020) and the WHO (2020) continue to insist, prevention of infection and spread implies personal and group hygiene such as the continuous and frequent use of running water for hand-wash, the need to bend your elbow over when coughing, staying at home when sick, and when going into public spaces is inevitable, wearing cloth face-covering while social distancing if possible. According to Sackey et al (2021), these legally mandating basic personal hygiene has changed the phase of public-private interactions.

Though early treatment was through therapeutic drugs and nutritional supplements, the raise for the vaccine (Sackey et al. 2021; WHO, 2020; The John Hopkins et al., 2020) spearheaded by the United States of America begun to bear fruit in the last quarter of 2020 after development commenced as early as in March 2020. On November 9, Pfizer of New York and BioNTech (a German company) announced the historic breakthrough of their coronavirus vaccine with an efficacy rate exceeding the 90 per cent threshold. Subsequently, by December 11, the US Food and Drug Administration (FDA) granted its first emergency usage authorization for coronavirus vaccines (C. Zimmer, J. Corum and S. Wee (2021)). This was consequentially followed by the WHO, EU and many other states as vaccines development successes began to spread across the pharmaceutical industries worldwide. According to the WHO, July 152021 cemented a total of $3,402,275,866$ administered vaccine doses (2021).

Within the maritime industry, the cruise ship industry and naval vessels were among the first marine crafts to have been hit with the spread of infection in the early days, suggesting the potential health dangers faced by the seafaring and marine professionals at the time (Sackey et al, 2021). Therefore, per K. Whiting's assessment of Covid-19 impact in the maritime industry segregated to include, (2020) concerns for the provision of health and safety protection of crew and vessel worksite, the 58 workers who tested positive for COVID-19 at the oil production facility operated by Tullow Oil off Ghana's western coast in the Gulf of Guinea (Reuters, 2020), is an example of the many incidences observed across the continental waters of Africa and the entire world's oceans, other concerns included (ii) ensuring crew are not marooned while (iii) preventing a halt in the global commodity supply system (Sackey et al., 2021; K. Whiting, 2020) - suggesting their inter relativity, except under extraordinary circumstances. Consequently, each of these challenges is discussed in subsequent sections of the study. 


\subsection{Shipping and Marine Operations amid the Covid-19 Health Crises}

The role of sea transport for global commodity shipping transport over the past one and half years amid the pandemic cannot be overemphasized-thus, a period that saw unprecedented uncertainty, and chaos across all nations, industries, and commerce. The African coast, just like the rest of the world's coast, has over the years been flooded with activities that maritime experts have classified into two broad categorical industries namely; the maritime industry (thus refers to traditional commercial marine ventures dedicated to marine cargo transportation) and offshore energy industry (refers to the exploitation of resources such as hydrocarbon resource found under the sea as well as the most recent efforts into offshore wind farm projects) which all constitute the global commercial marine industry (Sackey et al., 2021; Lloyd's Maritime Institute (LMI) 2018).

While traditional commercial shipping maritime operations simply involve a single or more ship completing a voyage leg of ordinary carriage of goods from one port to another for affreightment, the non-traditional offshore marine operations ordinarily involve several specialized ships of varying capabilities engaged in varying capacities on a single project such as the development of an oil and gas production field under an engineering contract. This goes to suggest that the men and women forming a ship's crew who dedicated their time and service to trade during the pandemic had to work under very difficult situations on board the various ships. The impact of the covid-19 pandemic could therefore be examined in regards to the ship manning structure of the various ships as well as the type of trade, in this case; reference is to vessel classified under the Safety of Life at Sea convention (SOLAS 74) as passenger vessels, which tends to determine the levels of social, physical and psychological health impact they could suffer. According to the IMO (2021), though there are no universally applicable definitions for the various ship types, specific descriptions and names are applicable per treaties and conventions of IMO such as SOLAS $1 / 2$

Therefore, ship inspector J. Toepfer (2016) indicated in an online article that the required crew size of any vessel under operation are dictated by the document referred to as the "Minimum Safe Manning Certificate," which stipulates the minimum number of personnel needed to safely navigate and operate the said vessel from position A to B under the Maritime Labour Convention, MLC 2006. He further noted the requirement did not take into account other considerations such as company administrative requirements. Hence, vessels often do have more crew beyond the required Minimum Safe Manning Certificate to aid in the distribution workload necessary to ensure adequate rest and effective performance from the ship's crew. According to J. Toepfer (2016), a typical marine vessel crewing is as shown in Fig 1.

For the non-traditional maritime industry, with particular reference to the commercial offshore industry -dedicated to providing global energy commodities such as fossil fuel, and wind energy (DNV GL, 2020); where the specialized marine vessels are ordinarily used in these fields developments. These highly specialised ships are operated beyond the minimum manning requirements during engagement in offshore marine operations (Sackey, 2021) with each crew serving a straight $12 \mathrm{hr}$ shift. And thus reverting to the minimum manning requirement (popularly referred to in the offshore industry as skeleton crew) and routing 8 to 10 hours work schedules with adequate rest periods per MLC 2006 requirement when not engaged in contracted offshore operations. According to Sackey (2021), most of these specialized ships with capabilities beyond simple navigation to maintaining dynamic positions at sea, as well as undertaking delicate ship manoeuvrings, serve as engineering construction platforms on which subsea-to-surface heavy-lift construction, subsea survey, pipeline production, and decommissioning operations are undertaking. Operations may include routing lifting to heavy-lift operations with cranes, subsea surveys and construction installations with remotely operated marine vehicles (ROVs), diving operations and so forth [Sackey 2021; Sackey et al., 2021; LMI, 2018]. Therefore, the manning requirement of these vessels when in operation vary from when not in operations per load of work at the given time. Besides the excess ship crew per the minimum manning requirement, SOLAS 74 classifies the extra men and women who make up the offshore project crew as passengers. Hence, these vessels in line with safety when engaged on projects per the SOLAS 74 convention, are classified as passenger's vessels over the duration of operations. Vessels of this nature can accommodate as high as over 100 plus crew (Sackey 2021), who are all under the command of the shipmaster while onboard - consultation with the offshore construction manager (OCM). With this background, it is easy to appreciate how such covid-19 impact may have on both segments of the commercial marine industry in terms of manning and operations. It is worth noting that due to local content regulations governing the offshore industries of Africa, which serves to increase the labour force of African descent on the various offshore projects within their national boundaries, the pandemic's impact should be relevantly studied. The health risk infection of Covid-19 therefore may be limited to vessel crew and their interruptions shore maritime professionals (Sackey et al, 2021). It is however unclear at what stage thus whether prior to mobilization, during marine operations (at sea, port and offshore facility locations), and during disembarkation periods, infections occur. These stages in line with vessel crew management are discussed in the proceeding paragraphs.

\subsubsection{Pre-mobilization, Mobilization, and Demobilization amid Covid-19: the notable Constraints}

Ship crew mobilization is a huge human resource management market within the maritime industry with major third-party players such as V.Crew of V.Group with a network of over 44,000 seafarers (Vouvray Acquisition Limited, 2021), and Worldwide Recruitment Solutions (WRS), which sources crew for various clients across the world. In this case, the above-mentioned subjects are examined concerning the two critical concepts of crew management, thus ship crewing and crew change management. According to Marlow Navigation (2015), the concept of crew management for ships ordinarily incorporates a variety of activities that are handled by crew management companies and their contracted manning agencies. Thus, the responsibility for providing the manning capacity needed by vessels occur under a crew management contract between ship-owner and crew Management Company. These activities encompass the sourcing, recruitment, selection, and deployment process. Other activities include scheduling, training/upgrading programs, and ongoing management of seafarers engaged on the vessels under crew management contracts. Essentially, the crew administrative aspects, such as "payroll services, travel arrangements, insurance, assistance with health, banking \& financial services, career guidance, communication duties, as well as team-building and family/social programs" are catered for (Marlow Navigation, 2015). The challenge of obtaining the required sourcing, mobilising and deploying hundreds of multinational contractors around the world (WRS, 2020) particularly in the offshore sector for a project, at the end of the first quarter of 2020 was compounded by the onset of the global pandemic declaration and a 'tyranny' of heavy travel restriction (Sackey et al., 2021).

Page $4 / 18$ 


\section{(a) The Concept of Ship Crewing:}

Historically, crewing of ships are achieve for the various ship divisions, namely; (1) the deck department (with the primary responsibility of steering, keeping lookout, handling lines in docking and undocking, and performing at-sea maintenance on vessel hull and non-machinery components), (2) the engine department (thus operated machinery and performed at-sea maintenance), and (3) the stewards' department (which does the work similar to hotel staff for crew and passengers) (see Fig 1 detail structure). The current sourcing of seafaring staff with the ranks of ratings for the international shipping industry, is majorly pooled from developing countries, especially the Far East and South-East Asia. This includes the Philippines (Filipino seamen), India and China. Whereas the OECD countries including North America, Western Europe, and Japan serves as a major source for officer recruitment. However, increasingly, officers are now been recruited from the Far East and Eastern Europe (i.e., Ukraine, Russia, Croatia and Latvia). Others include Greece, Japan and the United Kingdom (Seaman Republic (2016)). Africa seafaring as it stands today constitutes only 2 per cent of the world pool (Blédé, 2015). However, researchers have no sighted any data of the total marine professional population on the continent, especially the current population working within the offshore locations and port facility locations who interfaces with ships periodically. Nonetheless, news of positive covid-19 test cases that occurred offshore Ghana (Reuters, 2020) for example, signals the impact of Covid-19 subtended on the industry and the various interfaces despite the stringent protocols that were in place along the crew supply chain. While most industries during this pandemic resulted in remote operations (The European Business Review, 2020), most ships and maritime operations across the board could not function without meeting it's manning requirements. This includes FPSOs available fuel and energy supply, and cargo carriers transporting the needed food, medicines and consumables.

\section{(b) The Concept of Crew Change:}

is regarded as one of the most complicated tasks traditionally carried out at sea offshore locations or anchorages, and within port facilities -mostly during a port calls for ships. This stream of activities is hence, performed against the clock to enable ships to continue with normal operations with the required set of crew on time (José Salama, 2016). According to J Salama (2016), the process of crew occurs typically, when a cargo ship approaches a coastal city to make a port call, contacts a port agency, and make an official request. J. Salama suggests such requests to the port agency are not mostly limited to a change in the crew list. Therefore, J. Salama (2016) defines crew change as a series of activities that "consist of replacing one of the ship's crew members with another one. This action must be previously authorized by the ship's Captain and it is outsourced to port agencies."

According to J. Salama (2016), a typical modus operandi follows: (i) the receipt of Captain's request for processing at a fee, (ii) the processing involves managing all the necessary documentation (such as port pass, visas for the disembarking crew), (iii)ensuring the coordination of the embarkation and disembarkation of each corresponding crew member, (iv) where necessary, managing the ferry trips between offshore locations and the port as well as the transfer and collection of the crewmember from airport to ship boarding locations, and finally, (v) when necessary, booking of hotel accommodation for the crew member returning to their place of origin due to scheduled flight time. Extra services when required are provided under the terms of service.

These durable processes today have come under very difficult constraints according to SAFETY4SEA (2021), International Maritime Organization (IMO, 2021) and the UK P \& I Club (2020), who all bemoaned the Covid-19 situation that had paralysed supply chains and the movement of people. The IMO (2021) insist seafarers are unsung heroes amidst the pandemic, ensuring the transport of more than $80 \%$ of trade by volume, including vital food and medical goods, energy and raw materials, as well as manufactured goods were made available across the globe when needed. The IMO (2021) also claims an estimated number of 200,000 seafarers remain onboard commercial vessels and are unable to be repatriated past the expiry of their contracts as of March 2021 . Thus averting the ongoing problem remains vital at preventing fatigue and protecting the seafarers' health, safety and wellbeing (IMO, 2021).

The IMO (2021) further alluded to the difficulties "surrounding repatriation and crew changes" as having had a major negative impact on the shipping industry, which resulted in various calls for immediate interventions. Such interventions included the various IMO resolutions that called on "Governments to designate seafarers as key workers" as adopted by IMO, the United Nations General Assembly and the International Labour Organization (ILO). The IMO (2021) recounts that there have been situations where seafarers are denied access to medical care ashore despite the urgency of treatment needed that was unrelated to covid19. This raises further concerns for seafarers, the owner, and ship and crew management teams. With the availability and inoculation of Covid-19 vaccines currently ongoing, the situation remains unclear whether seafarers are accorded the needed attention and care sort by their crew management teams from the various national authorities. Bloomberg (2021) and Zeymarine (2021) reported the current threat to the shipping industry as the slow vaccination of seafarers while citing an incident of a ship docking with covid-19 infected Filipino crew at a period the Philippines, India and many other countries struggle with vaccine shortages. Herewith, Belgium is the first country within the European Union to commence a program providing COVID-19 vaccinations for seafarers. The International Transport Federation, ITF affirmed efforts by the Dutch government partnered with shipowners and local unions in vaccinating 49,000 seafarers. Also, efforts are continuing at major ports around the United States (Zeymarine, 2021). According to Michael Safi (2021), developing countries will not achieve mass immunization until 2024- having about $90 \%$ of the population within 67 low-income countries. The situation places a burden on the 900,000 individuals from developing countries who constitute the world's seafaring community (Zeymarine, 2021).

This notwithstanding, it is essential to note in summary that crew management services are an essential part of maritime and ship management-focused on ensuring there is manpower capacity for various activities handled by crew on-board vessels, as well as related administrative issues that shore-based. According to Wilhelmsen (2021), their efforts are expected to comply with the ISM Code, ISO 9001:2014, and ISO 14001:2014 Standards Standards. Det Norske Veritas group (DNV GL) (2021) also note that crew management today makes use of technology. Thus ship crew management software, are today designed to support the crewing process across the entire marine crewing pool while enabling optimization of vessel crew deployment. Thus having access to relevant data and reports accessible onboard and onshore. This development certainly has played a critical role amid the pandemic.

\subsubsection{Marine Operations and the Routing Duties of a Ship's Crew}


Given that the impact of Covid-19 over the past year have been felt on all sectors of the world economy, almost at all workplaces and on nearly all forms of operations including the maritime operations, identifying some of these critical operations carried out by seafarers that bares a potential interface to Covid-19. Traditionally, the marine operation responsibilities of a ship's crew are briefly discussed below.

\section{General Maintenance Operations}

According to Vance, J. E. et al. (2020), ships have general requirement maintenance similar to that of large buildings. Additionally, they do unique maintenance requirements, usually of magnitude obscuring the similarities to shore maintenance. Repairing marine damage from salts of seawater, carried by spray to all exterior surfaces, results in corrosion to common shipbuilding-steels, unlike corrosion-resistant materials that are too expensive for general use. The maintenance is usually by a protective coating to rust control. Hence, cleaning deteriorated surfaces and repainting remains the largest maintenance task for most 20th-century ships. The rapid development of coatings technology capable of protecting steel surfaces as better adhesives that are more resistant to reacting with seawater salts is said to be the major factor leading to a reduction of ship crew sizes (Vance et al., 2020).

\section{Machinery Maintenance}

Machinery maintenance expected to be carried out along a ship's propulsion machinery largely depends on machinery type. In the case of a steam turbine propulsion plant, the major maintenance items are associated with the boilers. Given that boiler tubes in the cause of operations may be subject to fouling on the waterside section and the hot gas side sections, they may require periodic cleaning. Again, occasional renewal may be required for the refractory material ("firebrick") used in a boiler furnace. Essentially, boilers are fired pressure vessels and thus are under legal stricture to be periodic inspected for safety. This requires its removal from service and opening (Vance et al., 2020). Similarly, other machinery types such as diesel propulsion plants, including the main engine due to high temperatures suffer from wear and tear as well as corrosion, and may need extensive maintenance of overhauling and part replacement. The inspection requirements hence, brings in sharp focus the attendances of marine and ship inspectors onboard along with vessel crew amid the spread of the covid-19 virus (Vance et al., 2020).

\section{Cargo handling Operations}

Vance et al. (2020), asserted that commercial ships are linked by their "trade route" allowing goods to flow by sea link. This comprises both short and long voyages and implies proper care be taken to ensure the goods while aboard the ship remain safe and protected. In turn, these goods must not pose a hazard to the ship and its crew. The ship's cargo operations as stated earlier including its care onboard remains the responsibility of the chief officer whose is aided by other staff.

Ship-shore transfer Cargo operations: over the years have seen significant advancement in terms of technological support from manually handling, running derrick and rigging gears to the use of cranes. This includes auxiliary and main cranes, and grabbers for lifting various loads and cargo such as grains, cement, clinker, cocoa beans, and bauxite. It is also a commonplace to find a group of men working together to develop the needed force to lift an object far heavier than a single man-load (Vance et al, 2020) (thus manual handling occur both in port and offshore locations). Shipside labour provided by dock labour companies (Ghana Dock Labour, 2021) is a common sight in most African ports, assisting in the discharge and loading of various forms of cargo. Their presence and activities are mostly associated with the duties of supercargo within loading or discharge ports. It is essential to note that cargo handling aboard ships for sea passage depends on the cargo type and the general exigencies of the transportation such as perishable goods carried in refrigerated containers, or freezer vessels. For freezer containers, an external adequate electric power supply arrangement must be made for freezing the goods (Vance et al., 2020).

In the offshore energy industry, however, the number of personnel to the level of maintenance and marine operations vary significantly depending on installed pieces of machinery operational both on deck and in engine room spaces (Sackey, 2021).

\subsection{The Current Developments Spearheading COVID-19 Regulations and Policies Focus}

Sackey et al (2021), note the rise in national and international restrictive regulations and policies worldwide guided by the WHO's mandated guidelines (WHO, 2020) to curtail the spread Covid-19 virus. The regulations though varied in the extent of implementation and timelines across the world, can be grouped into; (a) movement or travel restrictions (restricting the movement of persons from place to place.), and (b) Public Order Mandates (includes a need for social distancing, behavioural mandates on personal hygiene and order restriction such as the ban on the mass social gathering, and social businesses) (Sackey et al., 2021).

Within the maritime sector, several resolutions were passed to be enforced by member states of the IMO. These resolutions focused primarily on vessel crew and maritime professionals, by highlighting the concern of; (i) according to them "essential status" privileges in the performance of duty. Thus under the IMO Circular Letter No. 4204/Add. 6 and IMO Circular Letter No. 4204/Add.18 also known as "Key Worker" status call (measures to facilitate ship crew changes in seaports during the coronavirus (COVID-19) pandemic), (ii) addressing the Crew change crises under IMO Circular letter No. 4204/Add. 14, IMO Briefing 15, and Port State Control (framework of protocols for ensuring safe ship crew changes and travel). Others include resolutions for personal protective equipment (CL.4204/Add.15), seafarers certificates (CL.4204/Add.19) and ensuring a safe shipboard interface between ship and shore-based personnel (CL.4204/Add.16) (IMO, 2021). The IMO recognizes the violations to seafarers right stipulated under Regulation 2.5 of ILO's Maritime Labour Convention (MLC) - stating "seafarers have a right to be repatriated at the end of their contracts," as they work to end these violations as a result of measure implemented war off covid-19 spread (IMO, 2021). Presently, these travel restrictions are easing out following the successful production and continuous inoculations of people across the world with the Covid-19 vaccine. Within the maritime sector, these developments are seen as good news as they may pave way for the much-needed crew changes. 
Conversations have continued concerning violations by Flag and coastal states of the ILO MLC 2006 Regulations 2.5, for instance, providing facilitation of repatriation and replacement of seafarers serving on board ships, which Premti and Asariotis (2021) suggest could be linked to the current state of ratification of ILO Member States. Thus, unlike the ratification of ILO MLC 2006, the IMO Convention on Facilitation of International Maritime Traffic, 1965 (FAL Convention) is widely ratified. Assertively, some provisions in the latest amendments, have called for recognition of seafarers' identity documents to serve as basic documents providing public authorities with the needed information relating to crew members on arrival or departure of ships. Again, the focus of the related instruments to the Convention seeks a national single window of seafarers' identity documents and their related databases (A. Premti and R. Asariotis, 2021).

These efforts are supported legally by the latest ILO Convention No. 185 on Seafarers' Identity Documents (Revised) 2003, and as amended in 2016. This instrument specifically regulates the issuance and harmonization of seafarers' identity documents issued by the national authorities of their national countries. The document succeeds the earlier ILO Convention No. 108 on Seafarers' Identity Documents, 1958 with 35 per cent ratification. It is stated that the benefits will exceed the immediate 2 million seafarers working and living aboard international trade ships, who are the potential beneficiary of these documents that conforms to the latest ICAO standards verifiable with the same equipment as an e-Passport. The goal is to "facilitate seafarers' entry and transit to join their ships, their disembarking in ports, and crossing international borders while enhancing security using an internationally recognized document."

However, less than 20 per cent of Member States have ratified the ILO Convention No. 185 with some implementation challenges that pre-date the pandemic requiring redress (A. Premti and R. Asariotis, 2021). Hence, Premti and Asariotis (2021) recommended labour supplying, flag and port States, consider becoming parties to the conventions and aid in the implementation of the latest relevant versions pertaining to the international legal instruments under the current circumstances.

\subsection{Notable Seafarer Experiences from Covid-19 Impacts Observed across the World}

Direct infections early on from the Covid-19 viruses, according to the WHO, was the first reported onboard the Grand Princess with over 700 infection and 14 deaths -accounting for over half reported cases of SARS-CoV-2 outside of mainland China (Wikipedia, 2020). Subsequently, there have been dozens of reported infection rates from cruise ships to other commercial ships and offshore platforms. This includes several FPSO units and Rigs in the offshore oil industry of which Ghana's FPSO Kwame Nkrumah recorded 60 case infections offshore (Rueters, 2020; Eoin 0'Cinneide, 2020), and Shell's Nelson rig recording 14 cases of infection (BBC, 2020). Besides media reports suggesting the myriad of problems, the seafarer community and marine professionals are exposed to -highlighted by Sackey et al., (2021) to include risk to their health, employment, finances and overall social well-being, Radic et al. (2020) closely examined the psychological effect on a cruise ship's crew. They found that aside from the health implication from Covid-19 infections, depression was a profound medical illness among the crew- suggesting seafarers were more susceptible to diverse mental health disorders including depression [Sau and Bhakta, 2019; Radic et al. (2020)]. Radic et al. (2020) subsequently related the condition of depression to concerns of poor human resource management strategies lacking contingency planning for managing health and epidemiological type crisis, and social isolation onboard [Alpert, 2009; Radic et al. 2020]. The situation was compounded by pervasive maroon that cruise ship employees suffered at sea for months [Dolven, 2020; Radic et al. 2020] due to the COVID-19 pandemic. With rising case infection globally, the new challenge set forth a series of restrictions which meant businesses, including MWS and their customers had no option but to adapt to the changing environment of regulations. Detail of these health policies and regulations in the aftermath of Covid-19 is explained below.

\subsection{Notable Innovative Solutions associated with Continuous Global Marine Operation}

As discussed in earlier sections, the challenges faced by seafarers and marine professionals amid the pandemic are numerous. Some measures implemented to alleviate some of the problems have been diplomatic, thus the call via various policy resolutions (IMO, 2021, Sackey et al., 2021) on various national authorities to accord special concession on restrictive regulation on seafarers and marine professionals. Other measures have been the provision of technical support to aid seafarers' social interaction against depression. Internet data services were provided to help the industry cope with the strain (Sackey et al., 2021; Thetius, 2020). In the oil and gas industry, accelerated digital technologies like remote inspections and Al-driven operations adapted, help with coping in the crisis including the need to adapt to transitional energy markets emerging (Sackey et al., 2021; The Maritime Standard, 2020).

\subsection{Research Methodology 3.1 Study design and scope}

The study follows a case study approach towards developing an understanding of the current situational conditions Covid-19 and its related concerns have subjected the African seafarers and maritime professionals onboard vessels amid the pandemic. Due to heavy restrictive regulations that continue to remain even as various countries go through different faces of the pandemic while opening up economically, the study planned was carried out in stages as and when access was made available.

The study was delimited by access granted to the researchers on the field. Maritime operations observed over the period took into account operations offshore and within port facilities limited to the Gulf of Guinea region. The study areas encompassed operations in Ghana's maritime boundary. The other study areas included Ivory Coast, Nigeria and Angola maritime boundaries. These national maritime boundaries were select base on accessibility to researchers, and their strong maritime and offshore presence in the West African Sub region that continued through function amid the pandemic under grave constrains. Given that the study's concern focused on the raging Covid-19 public health crises, protocols and restrictions across these countries of interest encompassing travel constraints, hotel protocols, marine facilities and operations, the study limits its scope to the above described periods of varying operations. The scope chosen 
is in sync with the general business trend across the region as suggested by Sackey et al (2021). The approach will primarily be a mixed qualitative and quantitative account per description.

\subsection{Structure of the Study}

The study structure comprises the three distinct activities described below. Thus shown in Fig. 2. snip

Based on these designed stages, the study proceeds to examine the entire African context soliciting experiences of sampled seafarers and a select group of marine professionals available to the researchers. The study then makes use of a narrative element in describing the observation of operations amid the pandemic during site attendances under study.

\subsubsection{Sample Size}

The samples chosen for this study are a fraction of the seafaring community and marine professionals who work in the maritime and offshore industry across Africa. These are with varying degrees of experience. Sample size (1) constitute ten (10) purposively selected expert respondents engaged in interview sessions (see Table 1). Table 1 below is a list of crucial experts interviewed.

Table 1

Sample Size (1) - Selected Interview Respondent

\begin{tabular}{|lll|}
\hline RESOURCE PERSON & DATE & SCOPE \\
\hline Marine Surveyors & $24-10-2020$ & MWS Survey practice and situational awareness \\
\hline HSE \& Deck Crew & $(15-19)-02-2020$ & Operations safety and situational awareness \\
\hline Safety Officer & $(15-18)-06-2020$ & Health and safety concerns \\
\hline Ship Agent/ Ivory Coast & $23-03-2021$ & Ship Management concerns \\
\hline Crew management & $11-02-2020$ & Crew (dis) embarkation \\
\hline Pipeline Pressure Test Engineer & $15-07-2021$ & Survey concerns \\
\hline Chief officer and Master & $10-10-2020$ & Club Survey \\
\hline Statutory Surveyor & $20-10-2020$ & Statutory \\
\hline Crew operation Manager & $16-09-2020$ & Crew management \& Quarantine \\
\hline Marine Cargo Surveyor & $18-10-2020$ & Cargo \\
\hline
\end{tabular}

Sample size (2) shown in Table 2, constitute the random sampling of 100 seafarers and offshore marine professionals of various nationalities whose experience aboard ships encompasses time spent on traditional ocean-going ships and offshore specialized vessels. However, 71 individuals actually were able to respond to surveys per time constraints The two samples selected from the population of seafaring and marine professionals was empirical to projecting a clearer understanding of sentiments among these population in the areas of interest, and ascertain if there are any convergence between experiences of senior rank members (largely constituting sample (1) shown in Table 1) and non-senior members of the population.

Table 2

Respondent to Survey Questionnaires

\begin{tabular}{|lll|}
\hline Population & Sample Size & Actual Respondent \\
\hline Seafarers and Offshore marine professionals & 100 & 71 \\
\hline
\end{tabular}

Data Gathering process: the data gathering process followed Sackey et al.'s (2021) approach -taken into account the overall survey requirement to gauge opinions of seafarers and marine professional, and the various attendances at study sites chosen for the study, which informed on data needs, analysis and the various sets of data gathering tools researchers' could rely on amid the pandemic restrictions. The study also factored in time and access during the gathering process which considerably impacted the primary data collection process and its sources. The instruments chosen for this research were questionnaires, personal observation and interviews of expert or 'eye witness' respondent. Thus the first and second stages of the study conducts site observations at various stages of the pandemic cycle between 2020 and 2021.

The third stage focused on online surveys, interviews in the first quarter of 2021. A review of secondary data is also carried out. The instruments chosen for the online survey (Google form and Linkedln survey) were deployed through various platforms such as mobile phone calls, including online text platforms the use of WhatsApp, Facebook Messenger and emails. Various literature materials from online articles, journals and webpages and news were also cited. These approaches were imperative due to Covid-19 health risk, protocols and regulations including various social distance requirements, travel restrictions and heightened health risks following the varying new strains. Direct and indirect interviews were conducted (see Appendix A). 
Data Analysis Process: the data analysis carried out from the study, which was mostly qualitative with slight quantitative data, followed a descriptive narrative as it deployed comparative arguments in developing the knowledge based on information obtained.

The architecture (shown in Fig. 3), is a slight modification of Sackey et al. (2021); Sackey and Lamptey (2019); Ellinor (2013) structure as it in cooperates the global health challenges and the dynamics geopolitical climates.

\subsection{Results, Analysis And Discussion}

Results herewith are discussed of the various field observations and experiences of researchers engaged on varying operations situated within the maritime boundaries four influential West African nations- juxtaposed to experiences of the selected experts interviewed along with the general sentiments among the seafaring and marine professionals gathered through survey. The discussions are detailed below.

\subsection{Background of Respondents}

Background of respondents from Table 1 \& 2 above, transcended most of the popular career groups found within the maritime and offshore domain which included, Roustabouts, Able-bodied seamen, deck and engine officers, welders, offshore Riggers, Subsea Project Engineers, Ship Agent, Crew Agents, HSE officers and Deck foreman (as seen in Fig 4). Others included marine surveyors, deck technician engineers and subsea pressure test technicians. The sum of experiences of the expert respondent amounted to 141 years with an average of 14 years from which four seasoned mariners accounting for 61 per cent of the experience. Thus 87years of 141years' total. These were in senior and middle management of operations whose work scope influenced other marine professionals. Respondents however, engaged in the survey constituted individuals of all demographic with occupational experience over $306 y e a r s-$ working on various roles on vessels. Together, the working experience of respondents in the industry amounts to $446 y e a r s$ which is significant to drive the perspective of the novel concerns resulting from Covid-19. With this background, researchers sort to ascertain the level of situational awareness from the pandemic.

\subsection{Covid-19 Situational Awareness by Respondent}

Researchers could not identified any one out of the respondents who were not aware of the current status of the global pandemic. When asked specifically if they were aware of the developments of covid-19 virus, the symptoms, the protocols in place at the worksite, if they are ever willing to help to end the spread, if they are aware of vaccine development, and if they are willing to get the vaccine inoculation. The general response showed high levels of awareness for the covid-19 health crises (Sackey et al, 2021), as some were observant of the information regarding the progressive changes in viral variants of SARS-CoV-2 since originating from China, which include the UK, the Brazilian variant, and the current Delta variant from South Africa. Others referred to the first and second waves of spread of infection as the most sensitive moments that characterized their careers as businesses were forced to close -leading to contract cancellation, suspension and forfeiture. Concerning symptoms, each respondent had no struggle recollecting one or two out of the catalogue of symptoms to look out for when scanning their immediate environment, which were consistent with the WHO's (2020) symptom list. Respondents had no issue recollecting the very immediate covid-19 protocols - prior to embarkation, on their Jobsite and during disembarkation, and essence to ensure strict adherence at all times. However, a handful indicated the discomfort in most occasion at complying with all these protocol -suggesting their interest in securing an alternative. These findings agree with Sackey et al.'s (2021) findings. Again, all respondent showed great awareness of the vaccine developments (citing vaccines from Pfizer, COVAS, JOHNSON\&JOHNSON, and ASTRA) and rising inoculations across the world. Essentially, those who consented willingly to getting vaccine inoculation if offered constituted only one-third (33 per cent) of the total population of 81 . Two-third (66.67 per cent) of the respondents indicated they will accept to have the covid-19 vaccine when it is made a job-mandate. The high prevalence of resistance occurred before the first vaccine was announced. The study however, observes a growing interest as public education continue in Africa.

\subsection{Nature of marine operations impacted by Covid-19}

Noting that, regardless of the covid-19 pandemic crises and restriction, marine vessels have continued to move from port or offshore facility to port and vice versa in the region, whereas operations of all forms on offshore site and port locations have also continued, respondents were then asked what had been the impact of the pandemic on operations. Respondents were quick to point out that the situation have had a great impact on their work during operations over since March 2020 (See Appendix B for images of some major operations). Some noted several incidences of time out called amid operations in order to brief crew concerning reported rumor of covid-19 situation that created a lot of anxiety and agitations among some crew members offshore Ghana. The foundation of the problem been a crew change that occurred right within the early stages of border closure and travel restriction in Ghana following the first imported case into the country from Europe. Researchers observed this "timeout" call effort helped coil a volatile situation onboard one pipeline and heavy-lift construction vessel of over $300 \mathrm{crew}$ (thus foreign and local) over the period; as all crew were officially informed in a general meeting of the negative test of the suspected case though the individual was made to remain in isolation after boarding the vessel. Therefore, respondents attributed the volatile nature of events inflating passions and anger among some crewmembers to the level of anxiety, uncertainty and luck of relatable information in the early days of the pandemic. According to some respondents, these events impacted on the moral of crew. Their desire to see things return to normal was visible throughout their comments and discussions- affirming a general feeling amongst the various segments of marine professionals (Sackey et al., 2021).

\subsection{The Covid-19 Health Risk Concerns to Seafarers and Marine Professionals}

As Radic et al. (2020) illustrated in their study that the health crises currently been experienced by seafarers as a result of the Covid-19 pandemic is not limited to the covid-19 virus infection and the associated symptoms. But, that the covid-19 health crises have elicited strains of other health crises (mostly psychological in nature) unconsciously within the social cycle of both the affected and the unaffected individuals. Thus, therefore, the growing concerns over poor mental health today is unavoidable per research studies and media reports - had resultedin suicidal tendencies, while others are withdrawn due to stigmatization. 
These conditions of poor mental health were also observed by Radic et al. (2020) among the onboard crew of a crew ship. Notwithstanding the sensitive nature of the issue, respondents were asked if anyone at your worksite has ever tested positive from covid-19. Of the 304 respondents, 18.36 per cent offered to respond -well aware of the stigma surrounding Covid-19 despite the myriads of available public information and education across the world. Researchers intentionally weighed their responses against the condition that those responding were on active duty onboard ships at the time or only recently disembarked from their ships. For those who responded regardless of privacy concerns, results are as seen in Fig. 5.

Of those responses indicated in the chart, it can be seen that a majority of 62.50 per cent of respondents indicated they did not observe any incidence of a positive covid-19 test at their job worksite, whether during port calls or on travel. A little over 5 per cent were however unsure, claiming besides the fact that during embarkation quarantine, the crew was kept across various hotel facilities, whenever test was conducted, they were hardly disclosed openly. Therefore, they could not tell which of the crew was affected at any time despite the remorse. 32.14 per cent of the respondent, however, were certain of having witness positive covid-19 from the worksite. They explained that as time has weighed in on the covid-19 pandemic, much has been learned, and therefore a positive case is not as feared as before even of the rumour by ship crew. Some were happy to share their earlier experiences with researchers -claiming there were occasions remorse onboard led to agitation among some crew members when after a crew change earlier that day, an on-signer happen to have been seen displaying symptoms similar to covid-19. According to them, though the individual was subsequently quarantined, most crew members took offence and questioned the vessel management of reasons for the crew change amid the pandemic.

With these responses, researchers proceeded to examine their (personal) proximity to the covid-19 virus infection. Thus, again researchers sort to find out if any respondent or anyone close to the respondent has ever tested positive for the covid-19 virus. The results are therefore shown in Fig. 6.

From the chart, it can be seen that of the 19 per cent who responded to the query of the 305 respondents sampled, 69 per cent said no, they have never tested positive nor have any close relations of their tested positive for the covid-19 virus. 31 per cent, however, indicated to the affirmative. Those who indicated to the affirmative did not wish to explain the circumstances as according to them brought bad memories. They however shared with researchers that the situation led to delays in the embarkation of vessels, as well as having to also suffer from a state of depression. Others indicated they lost their job offers entirely without any form of compensation. Some suggest that the most difficult part is the moments' such news are broken to them concerning the laboratory test when they had patiently endure quarantine and were only few days away from mobilization. Given these comments, researchers proceeded to examine crew management operations over the time frame as discussed below.

\subsection{Covid-19 Protocols, Regulation and Policies Affecting Ship Crew Management Operations}

Respondents were subsequently asked whether they have notice any massive changes in crew management operations since the operationalization of national and international Covid-19 protocols, and did they find them useful and a healthy balance of their work and health. According to respondents, there was no doubt the measures were tough on any free born individual in the world who has been forced cope in this crises. This thus concur with Sackey et al.'s (2021) findings. As observed, none of the respondent was excited about the excessive restrictions and protocols. They were also neither in favour of allowing the pandemic to spread for the sake of keeping their freedoms. They indicated that normal situation of relatively basic arrangement for pre-mobilization, mobilization, post mobilization and disembarkation operations across all the chain of crew management under shipping and offshore operations have changed.

\subsubsection{Travel Protocols against Routes of Travel and Challenges Arising}

Several Covid-19 travel protocol are actively in place across the world since the onset of the pandemic. These protocols in practice are carried out at various interfaces where travelers and migrants patronize. These facilities include seaports, airports, hotels, road transport arrangements and restaurants. For seafaring and marine professionals who have had the reason to travel to their various workstations onboard ships offshore and at port facilities. Most have had varied experiences concerning implementation of travel restrictive protocols. Thus, the study observed that a typical seafarer's job required him or her to travel from home country, state or region in order to board the vessel for which the job employment contract is signed. Such operations entails securing boarding pass if vessel were in a port location. Depending on the proximity of the seafarer or marine professional's home to the vessel location, flight tickets are secured for their travel together with visa where necessary. Largely, travel protocols affecting their movement are those implemented at air and sea port facilities. These protocols can be categorized into:

(a) Airport or Seaport protocols specified by State Authority per national regulations - all travelers are required to present negative Covid-19 test case under $72 \mathrm{hrs}$ prior to receiving boarding pass for flight or vessel while ensuring adherence of all social protocols in public spaces.

(b) Flight Protocols per Airline requirements- all travelers are required to ensure adherence of social and personal hygiene protocols for covid-19 all through flight until disembarkations.

It is imperative to note here that most of these protocols forms part of the crew management guidelines handed over to ship crew and marine professionals attending to or leaving worksites. These instructions are regularly updated as per regular travel advice received during shipboard operations. Regardless of compliance with the protocols and of all efforts made by ship-owners, seafarers have continued to suffer from the overstayed contracts onboard ships partly due to concerns of unavailability of flights at the end of mandatory quarantine stay.

It is also essential to note that ship crew have occasionally disembarked ahead of contractual term due to emergencies. However, the covid-19 pandemic took this option away from most ship crew in the past year. A case in point is the recount of one of the most difficult situation observed by researchers while onboard. The case involved an elderly ship crew in his late 50s who received news of the passing of his aged father. This crew member is the breadwinner to his family. The vessel's construction management team offered the crew member sometime off away from construction operation on the offshore oil and gas field. However, the crew did not find the gesture useful and returned to the worksite -taking up lighter jobs on the vessel main deck (housing various heavy-lift

Page 10/18 
cranes, pipeline production plants and pipe storage unit), and only resorting to intermittent phone calls and browsing when away from construction area (in the vessel's accommodation unit) as much as possible to communicate with family members back home. All crew were empathetic to his inability to demobilized and head home to Malaysia from offshore Ghana. This case is similar to that of another crew member onboard the Seven Borealis who had to resort to calls and video chats on WhatsApp in order to be part of the burial of his mother. Flight as a means of travel in Africa continue to be one of the most underserved commerce and therefore availability and pricing are never guaranteed.

Again, seven crew members of general bulk carrier during loading in the port of Abidjan according to expert respondent who indicated they were scheduled for crew change upon berthing, were forced to remain onboard and to continue their service until the vessel had concluded the next voyage to Malaysia after crew management were unsuccessful in securing a flight from Abidjan to the Philippines. The respondent who also doubled as captain indicated that their relievers in this case, were also forced to continue to stay back in quarantine or return home until crew change is possible - raising issues of inconvenience and low morale amongst crew members. The respondent also noted the unavailability of berth at the most critical point in time during port call as another reason they had to grabble with. He passively added that crew change operations onboard ships cannot simply be compared to most land-based operations where systems can simply be shut down where necessary until the next hand takes over. With ships, there must be a man on watch at all times literally, he stated and therefore until your relieving crew show up on the ship all crew are expected to keep their duty post.

(c) Land Border routes and protocol - the use of land border crossing in migration amongst Africans appear and continuous to be the most effective migration channel especially in West Africa. Across the study regions researchers observed that international borders between neighbouring countries have remained closed since March 2020 whereas internal borders between cities, regions, counties remain open. Covid-19 protocols for commuters were largely limited to social distances and mandated personal hygiene prior to crossing each police, drug enforcement, customs or immigration barrier. There are no PCR test requirement for migrants who continue to cross the land borders.

Since most land borders in Africa still remain closed despite improvement in managing the covid-19 pandemic across the world, border communities and migrants in general have questioned the wisdom behind the delay in opening and in some instances staged demonstrations as report in the Ghanaian media of Afloa border next to Togo and Ellubo border next Ivory Coast. The reasons for these continues border closure remains unclear. Marine professionals such as Surveyors, Auditors and Seafarers who have had to attend to jobsites in locations near or in neighbouring countries, regions or towns with less or no available flight arrangements continue to use these land borders which still remain close for most west African nations as observed -hence, such migrants resorting to the use of unofficial routes at their own peril. These unofficial routes which include river bodies for which the use of canoes continue to serve border communities and migrants as a whole though there are no strict Covid-19 protocols for commuters. Respondents who made use of these land border crossing in the course of performing their duties indicated their disappointment with how special consideration are not given to them when attempting to the crossing the border as 'key workers' ensuring that the asset integrity of vessels ensure the safety of life at sea of all crew and property. Rather, they are turned back and they have had to resort to unapproved border crossing routes. They also indicated occasions where they witness diplomatic vehicle been let through the approved borders in their diplomatic vehicles. To them, clearly the voice of IMO and major stakeholders through the resolution did not resonate in the boundaries of their members states as border security personnel were unaware or adamant of the protocol via the December 012020 resolution.

Given that the December 012020 UN IMO resolution categorizes seafarers and marine professionals as 'key workers' to aid their movement between their jobsites (ships and ports) and their native homes, it is naturally expected that such individual wielding identity cards and complying with protocol are given access to freely pass across any national border - be it land, sea or air space provided they have the required documentary evidence.

\title{
4.5.2 Quarantine Requirement for Seafarers
}

\author{
a) The Ghanaian Scenario as Observed
}

The 14 day quarantine requirement for Covid-19 is continually been implemented across the world. In Ghana, while a 10 to 14 days quarantine was strictly required of expat professionals entering the country and attending to offshore operations, due to the need for cost cutting measures, the quarantine period for designated local crew during embarkation was split into two periods. The first three to six days are periods of self-isolations at home. During the self-isolation period, the Health and Safety officer of the crew management institution conducted unannounced video calls to determine the levels of adherence to the requirement. An eight days quarantine then proceeds embarkation for which a covid-19 test is carried out $72 \mathrm{hrs}$ ahead. A daily record of temperature of each persons in isolation within the hotel is taking by quarantine officers for the operators. These quarantine protocols observed in Ghana were largely similarly and varied slight to those observed in Angola. As observed by researchers on offshore site observation, the following itemized events characterizes covi-19 protocol of both foreign and local nationals whose professional duties places them onboard ships at remote locations.

\section{b) The Angolan Scenario as Observed}

Whilst in self-isolation, a daily log of your temperature and blood pressure will be taken by a dedicated doctor/nurse. For foreigners, beside the mandatory PCR Test required at the various airport units from place of departure and place of arrival, the quarantine PCR test is also demanded.

Thus, these records plus another negative test certificate to be issued is required by the ministry of health and shipping agents on the day of transfer embarkation aboard the surfer boat designated to conduct the transfer of the crew from shore facility to the remote offshore platform or vessel.

Again, once onboard the designated vessel or FPSO unit at the offshore location, the following rules apply:

1. Clothes are isolated $72 \mathrm{hrs}$ before sending to the laundry.

2. The onboard medic, takes a daily log of all POB.

3. A rapid PCR Covid-19 test is done on day 8.

4. All items from transfer boat etc. are quarantined for $24 \mathrm{hrs}$ before any personnel is allowed to physically handle / touch them. 
5. The usual hand washing is encouraged and hand gel are made available at each door to encourage sanitization.

It is also observed that work rotations are now 6-8 weeks aside the quarantine days, hence, a total of 10 weeks per trip is completed by each crew regardless.

Once the crew disembarks and arrivals onshore, a COVID-19 PCR test is again required over the next 72 prior to flight departure for any foreign crew.

Again, depending on the government rules and policies concerning an expat staff's region of dwelling, he or she may be required to undergo a mandatory 10 days quarantine. In this case, a negative covid-19 test result is required on both day 2 and day 8 of the quarantine period. As a result of these measures, a max of 12-14 weeks have become current length of days marine offshore personnel endure over a 12hrs daily shift away from home.

Similarly, in Ivory Coast and Liberia as observed, PRC test results were demanded of any crew by government and ship owners prior to entry in the seaport and subsequent embarkation. These measures appeared to have been effectively implemented in certain sections of the sea port in Abidjan. It was however not the case at the remote sea port of Greeneville in Liberia dedicated to bulk carrier transporting timber logs or lumber product.

\subsubsection{Boarding and Disembarkation Arrangements}

Personnel transfer between remote offshore facilities and land-based facilities continue to make use of choppers, supply boats and surfer boats. In offshore Ghana, chopper transfer appeared to be the dominant of the 3 mode of personnel transfer within the cape three western basin for the 3 FPSO units. In Angola, the surfer appear to be the most dominant means of personnel transfer. However, during subsea construction operations, pre-mobilization embarkations in Ghana were largely carried out at the seaport where the construction vessels made use of the bulk carrier berthing in Takoradi port. This allowed for large sets of crew size such as 300 in a single embarkation operation. These operations are carried out with covid-19 protocols implemented in the port area of embarkation. Crew are required to comply with covid-19 at all times while they are on the wharf awaiting boarding via gangway. Researchers did not cite any data on any covid-19 positive case during such operations in the port.

According to respondents despite the current requirement of negative PCR test required to embark on marine vessels within offshore Ghana, in much recent times, priority is been given to those crew members with Covid-19 vaccination inoculations. These have caused some level of uncertainty amongst some local seafarers who prior to the new guidelines have signed contracts and were on standby -awaiting embarkation. The news leading to forfeiture of their embarkation and subsequently their contracts clearly illustrates the continuous economic hardships covid-19 protocols are having on individuals. It is worth noting here that seafarers within Africa over the course of these covid- 19 era have received no financial relief and therefore mostly have had to rely of family for support as most indicated of their long stay at home.

\subsection{Other Concerns Raised by Marine Professionals and Seafarers}

Respondents when asked if there were other concerns they have had to face over the period, they all indicated to the affirmative, claiming majority of them over the cause of one and half years have suffered indiscriminate cancellation of contracts beside the challenge having to undertake overstayed contracts at some point in time. Others lamented of their concern of unpaid and reduce wages at short notice in violation of ILO MLC 2006 with the only reason given being the cost cutting measure on crew wages in order to support the excess cost of operations and to keep them at work. This is a sharp contrast to the incentives given to other 'key worker' group like the nurses and doctors during this fight against the covid-19 pandemic. Respondents believe leaders in the maritime industry need to do more than talk at various talking shows and conferences and demand real action from nations signatory to UN and IMO conventions. Some also suggested the legal violations were not only on the economic front but also extended to human right and health concerns.

They bemoaned the fact that this single event have the tendency of letting seafarers rethink their careers and opt for other professions. To them, once a noble profession now appear less valued in the society except when they dress up in their uniforms and appear at functions.

\subsection{Summary And Conclusion}

\subsection{Summary}

The study found that all respondents demonstrated a high level of awareness for the protocols and health risks they faced during site attendances. Marine vessels, offshore installations, and shore side facilities have also been at the forefront (Lloyd's Register, 2020) of the Covid-19 fight - providing the essential energy commodity to power innovation, healthcare, and economic sustenance. The challenges experienced due to the spread of Coronavirus is identified in an earlier section and classified into: (a) the risk to health crises as the spread continuous with not advance cure insight, and (b) the restrictive regulations crises forcing socioeconomic activities to shrink world over. Impact of the Covid-19 health and regulation crises as mentions above, has led to the economic fallout in terms of loss of business, high-cost to doing business, and the massive rush for innovative ways of staying in business. The sum of the working experiences of respondents engaged in the industry amounts to 446years which is significant to drive the perspective of the novel concerns resulting from Covid-19. With this background, researchers sort to ascertain the level of situational awareness from the pandemic. The general response showed high levels of awareness for the covid-19 health crises (Sackey et al, 2021), as some were observant of the information regarding the progressive changes in viral variants of SARS-CoV-2 since originating from China, which include the UK, the Brazilian variant, and the current Delta variant from South Africa. Marine vessels have continued to move from port or offshore facility to port and vice versa in the region, whereas operations of all forms on offshore site and port locations have also continued amidst the pandemic. The covid-19 health crises have elicited strains of other health crises (mostly psychological in nature) unconsciously within the social cycle of both the affected and the unaffected individuals. Respondents indicated that normal situation of relatively basic arrangement for pre-mobilization, mobilization, post mobilization and disembarkation operations across all the chain of crew management under shipping and offshore operations have changed as a result of restrictive covid-19 protocols. Respondents who constituted people mostly from Africa, and Asia have suffered indiscriminate cancellation of contracts beside the challenge having to undertake overstayed contracts at some point in time. Others lamented of their concern of unpaid and reduce wages at short notice in violation of ILO MLC 2006.

\subsection{Conclusion}

Page 12/18 
The study concludes asserting that the current covid-19 crises despite the over a year experience living with it, progress made in vaccine production and therapeutic, continue to pose a challenge to seafarers and marine professionals wellbeing. Despite the many pledges by IMO member states across the world, real efforts are yet to be seen that addresses the concerns of seafarers if the designation 'Key Worker status will ever have a meaning and inspire rather than demotivate members of the profession who have continued to ensure there is adequate supply of energy, food, medicines and consumable across the entire planet -helping avert a global catastrophe. It is essential for all concern to note that seafarer are parallel-militarily trained and therefore at best, have endured this hardship they have faced and violation of their rights without fringing. How long will policy makers continue to pay lips service with no tangible results?

While the Ad-hoc approach of learning and developing measures for aiding maritime operations by the IMO have managed to sustain the global supply chain of major commodity through the Covid-19 pandemic, the challenges resulted in major crises that have been detrimental to the survival of the seafaring trade but for the bravery of the men and women who dedicate their lives to ensure ships are operational. Therefore, lessons learnt within these period of history going forward should inform the need for a comprehensively developed a global emergency contingency regulatory plan that identifies various potential threats, establishes adequate measures and make adjustment for review and amendments.

Such a contingency regulatory plan will be expected to activate under the UN conference with the aid of the IMO and other stakeholder organizations and nations. A decentralized form of the plan is expected to be adopted by all UN member states as it will harmonise decision making and implemented measures. Such document ought to be made public for easy assimilation.

\section{Declarations}

Authors note that their judgment may or may not have been impaired by their affiliations with the study. However, the corresponding author wishes to state on behalf of all authors that at no stage did we receive any financial support.

\section{References}

Anila Premti and Regina Asariotis (2021 March 2). Facilitating crew changes and repatriation of seafarers during the COVID-19 pandemic and beyond. https://unctad.org/news/facilitating-crew-changes-and-repatriation-seafarers-during-covid-19-pandemic-and-beyond

ASME (2004). The Role of Marine Surveyor and Their Requirement for Selected Items. Retrieved at; http://citeseerx.ist.psu.edu/viewdoc/download? doi=10.1.1.656.3438\&rep=rep1\&type $=$ pdf

BBC, (2020). Covid: Workers taken off rigs after positive tests. https://www.bbc.com/news/uk-scotland-north-east-orkney-shetland-54537740

Bloomberg (2021 July 12). Shipping Chaos Not Going Away with Most Seafarers Unvaccinated. https://www.bloomberg.com/news/articles/2021-0712/shipping-chaos-not-going-away-with-most-seafarers-unvaccinated

Carl Zimmer, Jonathan Corum and Sui-Lee Wee (2021). Coronavirus Vaccine Tracker. https://www.nytimes.com/interactive/2020/science/coronavirusvaccine-tracker.html

CNS-NAE (2020) ABO Central Subsea Hydraulic Loss Emergency Subsea Intervention- Campaign 3. Unpublished Document, CNS Marine, Nigeria.

Det Norske Veritas group (DNV GL) (2021). Ship crew management software - ShipManager Crewing. https://www.dnv.com/services/ship-crew-managementsoftware-shipmanager-crewing-1535

DNVGL (2020) Offshore Wind. https://www.dnvgl.com/power-renewables/themes/offshore-wind/index.html

DNVGL (n. d) Remote Surveys for Fleet in Service. https://www.dnvgl.com/services/remote-surveys-for-fleet-in-service-

142702\#: :text=DNV\%20GL\%20offers\%20remote\%20surveys,surveyor\%20travel\%20to\%20the\%20vessel.

Douglas McCauley, Kristian Teleki, Gloria Fluxa Thienemann (2020) 8 ways to rebuild a stronger ocean economy after COVID-19.

https://www.weforum.org/agenda/2020/05/how-to-build-a-bluer-ocean-economy-after-cobid-19/

ECOWAS (2020) ECOWAS Guidelines Harmonisation and Facilitation of Cross-Border Trade and Transport COVID-19.

https://www.tralac.org/documents/resources/covid-19/regional/4091-ecowas-guidelines-harmonisation-and-facilitation-of-cross-border-trade-and-transportcovid-19-june-2020/file.html

ECOWAS (2020) ECOWAS Ministers Validate Reports on Ease of Business and CoronavirusControl. https://www.ecowas.int/ecowas-ministers-validate-reportson-ease-of-business-and-coronavirus-control/

Eoin O'Cinneide, (2020). Dozens test positive for Covid-19 on vessel working at Tullow's Jubilee field off Ghana.

https://www.upstreamonline.com/coronavirus/dozens-test-positive-for-covid-19-on-vessel-working-at-tullows-jubilee-field-off-ghana/2-1-817427

GARDAWORLD (2020) Ghana: Wearing of Face Mask Mandatory in Public in Greater Accra. www.garda.com

Ghana Dock Labour (2021). ABOUT US. https://docklabour.com/

Ghana Ports and Harbour Authority, GHPA (2020) Welcome Message. https://www.ghanaports.gov.gh/page/index/15/EXKGB1KA/Welcome-Message

Page $13 / 18$ 
Ghana Ports and Harbour Authority, GPHA (2020) Experts Predict An Economic Recession If Coronavirus Pandemic Exceeds Projected Timelines.

https://ghanaports.gov.gh/Media/news-details/84/EABLQJZL/EXPERTS-PREDICT-AN-ECONOMIC-RECESSION,-IF-CORONAVIRUS-PANDEMIC-EX... 3/3

Ghana Ports and Harbour Authority, GPHA (2020) Our History and Future. https://www.ghanaports.gov.gh/page/index/20/55QF2TKE/Our-History-and-Future

Google Satellite (2020) Ghana Map Road Network. Retrieved from;

https://www.google.com/maps/search/ghana+map+road+network/@5.6784738,-1.4565539,9z

Greg Naterer (2020) In the midst of coronavirus crisis lies great opportunity for Canada's offshore oil and gas industry. https://theconversation.com/in-themidst-of-coronavirus-crisis-lies-great-opportunity-for-canadas-offshore-oil-and-gas-industry-139638

GWEC - Global Wind Energy Council | Disclaimer (2020) Opportunities and challenges after COVID-19 for global Offshore Wind Industry. https://gwec.net/opportunities-and-challenges-after-covid-19-for-global-offshore-wind-industry/

Haynes and Boone, Andreas Dracoulis, Jonathan Morton (2020) COVID-19 and its impact on Offshore Construction. https://www.offshore-mag.com/businessbriefs/coronavirus/article/14178564/haynes-and-boone-covid19-and-its-impact-on-offshore-construction

International Maritime Organization (IMO) (2021). Crew changes: A humanitarian, safety and economic crisis.

https://www.imo.org/en/MediaCentre/HotTopics/Pages/FAQ-on-crew-changes-and-repatriation-of-seafarers.aspx

José Salama and Co Ltd, (2016). What is a crew change and how is it done? http://www.salama.es/en/noticia/ver/id/26/title/what-is-a-crew-change-andhow-is-it-done.html

Josiah Toepfer (2016). What was the typical crew of a cargo ship composed of?. https://www.quora.com/What-was-the-typical-crew-of-a-cargo-shipcomposed-of

KPMG-Ghana (2020) Ghana- Covid-19 - Related Travel Restrictions and Safety. https://home.kpmg/xx/en/home/insights/2020/03/flash-alert-2020094.html

Lee Hong Liang (2020) Shipping Has Reasons to Be Optimistic despite Serious Challenges https://www.seatrade-maritime.com/containers/shipping-hasreasons-be-optimistic-despite-serious-challenges

Lloyd's Maritime Institute (2018) Introduction to Marine Survey Profession: Module 1. Lecture Handout, Lloyds Maritime Institute, Geneva, Switzerland.

Lloyd's Register (2020) Long-term ambitions remain for offshore, despite challenges from COVID-19. https://www.Ir.org/en/insights/articles/long-termambitions-remain-for-offshore-despite-covid19-challenges/

M. J. Maekelae (2020) Equity and Human Right Right Commission: Covid-19 Restrictions and the Effect on Human Rights. http://equityhumanrights.com

Marlow Navigation (2015). WHAT IS CREW MANAGEMENT FOR SHIPS CREWING SERVICES? https://marlow-navigation.com/en/what-is-crew-managementservices.asp

Michael Safi (2021). Most poor nations 'will take until 2024 to achieve mass Covid-19 immunisation'.

https://www.theguardian.com/society/2021/jan/27/most-poor-nations-will-take-until-2024-to-achieve-mass-covid-19-immunisation

Ministry of Health, Ghana (2020) President Akufo-Addo Addresses Nation On Measures Taken By Gov't To Combat The Coronavirus Pandemic.

https://www.moh.gov.gh/president-akufo-addo-addresses-nation-on-measures-taken-by-govt-to-combat-the-coronavirus-pandemic/

MyJoyOnline (2020) 11,657 jobs lost due to Covid-19 - Employment Minister revealshttps://www.myjoyonline.com/news/11657-jobs-lost-due-to-covid-19employment-minister-reveals/

P. Zhou, X.-L. Yang, X.-G. Wang, B. Hu, L. Zhang, W. Zhang, H.-R. Si, Y. Zhu, B. Li, C.-L. Huang, et al. A pneumonia outbreak associated with a new coronavirus of probable bat origin. Nature, 579 (2020), pp. 270-273

Reuters (2020 May 29). Tullow Oil says 58 workers test positive for COVID-19 offshore Ghana. https://www.reuters.com/article/us-healthcare-coronavirustullow-ghana-idUSKBN2352Q6

Sackey, Anthony Djaba and Lamptey, Benjamin Lantei (2019) Activities of Local Fishermen Within Ghana's Offshore Construction Fields, Impact on Operations- Polar Onyx Experience. Regional Maritime University Journal Vol. 6, Accra Ghana

SAFETY4SEA (2021). IMO explores Pacific hub ports concept for crew change. https://safety4sea.com/imo-explores-pacific-hub-ports-concept-for-crewchange/?_cf_chl_jschl_tk_=5d7823576e56c099e43b7ec270244b6dec943ab1-1626634356-0-AVVXsm-

175a6BsHInkZzyPKsst6Cx7KkoTHoHqWfQInT5DLFwfOPMvkqiwkl1J2coZRcz6ytBQBS1wg2UrO3bBnjZQXmEAI0_pliXwi2glpUQh_PiUvMXCHLMKPxURileUrZT iKz8B3nD9PgJCM7jbwrqToJ0Mw3SKNQ_cvqadZSP3cUaL8meFY13wkHXqVTdOSS07uoEKOotw65FcVPpObEmPjb0tsm4GtDN3Mf9fc4dZ8eXdHMPkLjjtKelel 6mwAM6HE7FB5tjKM05H6rYcrtdiMbEnya-aQ8rAD1gr3UT4t0858TgGLCN66rdHSEXxQB2hacPI2qYZVmfyEqgeNC-WS_8I_hzv-

NyhAbiKhaZOfqsNBNfElo27zbcrdBJCoSe4RVDwhP0ZizSm4yVRyl9IWb27-R6xHcyv73EGDupkA

Page $14 / 18$ 
Seaman Republic (2016). Shortage of Seafarer Officers Seen from Latest BIMCO-ICS Manpower Report. http://www.seamanrepublic.com/2016/07/shortageof-seafarer-officers-seen-from-latest-bimbco-ics-manpower-report.html

STA Law Firm (2020) Overview: Impact Covid-19 on the Shipping and Maritime Industry. https://www.stalawfirm.com/en/blogs/view/covid-19-on-shippingand-maritime-industry.html

The European Business Review (2020). Remote Operations, Work-From-Home Employees and Moving Business Operations Online.

https://www.europeanbusinessreview.com/remote-operations-work-from-home-employees-and-moving-business-operations-online/

The John Hopkins University, The John Hopkins Hospital, and the John Hopkins Health System (2020) What is Coronavirus? https://www-hopkinsmedicineorg.cdn.ampproject.org/v/s/www.hopkinsmedicine.org/health/conditions-and-diseases/coronavirus?

amp_js_v=a6\&amp_gsa=1\&amp=true\&usqp=mq331AQFKAGwASA\%3D\#aoh=16039674132907\&referrer=https\%3A\%2F\%2Fwww.google.com\&amp_tf=From\%: and-diseases\%2Fcoronavirus

The Maritime Standard (TMS) (2020) Offshore Oil And Gas Sector Adapting Well To Covid-19 Challenges. Webinar Panel Discussion. https://www.themaritimestandard.com/offshore-oil-and-gas-sector-adapting-well-to-covid-19-challenges/

Thetius, (2020) Maritime Technology Initiatives Supporting The Industry Covid-19 response. Retrieved at https://thetius.com/maritime-technology-initiativessupporting-the-industry-covid-19-response/

TÜV-Rheinland (2013) Marine Warranty Survey Services. https://www.tuv.com/media/corporate/industrial_service/Marine_warranty_surveyTUV_Rheinland.pdf

U.N. Chronicle (2020) Innovation for a Sustainable Ocean amid theCOVID-19 Pandemic: Impacts on Kenya's Marine and Coastal Environment. https://www.un.org/en/un-chronicle/innovation-sustainable-ocean-amid-covid-19-pandemic-impacts-Kenya's-marine-and-coastal

U.S. Embassy in Ghana (2020) COVID-19 in Ghana. https://gh.usembassy.gov/ghana-covid-19-information/

UK P \& Club (2020). Covid-19: Crew changes. https://www.ukpandi.com/news-and-resources/crew-changes/

UNCTAD (2019) Review of Maritime Transport 2019 - UNCTAD. https://unctad.org/en/PublicationsLibrary/rmt2019_en.pdf

United Nations (2021). World Population Prospects (2019 Revision) - United Nations population estimates and projections. https://population.un.org/wpp/ United Nations Conference on Trade and Development (UNCTAD) (2020) Covid-19: A 10-Point Action Plan To Strengthen International Trade And Transport Facilitation In Times Of Pandemic. Policy Brief No. 79

Vance, J. E. , Woodward, . John B. , Stilwell, . James Joseph and Davies, . Ernest Albert John (2020, November 10). Ship. Encyclopedia Britannica. https://www.britannica.com/technology/ship

WHO (2020). Coronavirus disease (COVID-19). https://www.who.int/emergencies/diseases/novel-coronavirus-2019/question-and-answers-hub/q-adetail/coronavirus-disease-covid-19

WHO, (2021). WHO Coronavirus (COVID-19) Dashboard. https://covid19.who.int/

WIKIPEDIA, (2020). COVID-19 pandemic on cruise ships. https://en.wikipedia.org/wiki/COVID-19_pandemic_on_cruise_ships

Wilhelmsen (2021). Crew Management. https://www.wilhelmsen.com/ship-management/crew-management/

World Economic Forum (2020) How COVID-19 Is Impacting On Sea Crew And What Can Be Done. https://www.weforum.org/agenda/2020/06/shippingseafarers-covid-19-mental-health-supply-systems/

World Health Organisation, WHO (2020) Coronavirus Disease (COVID 19) Weekly Epidemiological Update and Weakly Operational Update. https://www.who.int/emergencies/diseases/novel-coronavirus-2019/situation-reports

World Health Organisation, WHO (2020) Update WHO recommendations for International Traffic in relation to Covid-19 Outbreak. https://www.who.int/newsroom/articles-detail/updated-who-recommendations-for-international-traffic-in-relation-tocovid-19-outbreak

World Population Review (2021). Africa Population 2021 -1,373,480,428. https://worldpopulationreview.com/continents/africa-population

Worldometer (2020). Countries in Africa: 54. https://www.worldometers.info/geography/how-many-countries-in-africa/

Worldwide Recruitment Solutions, WRS (2020). Marine Crew Management. https://www.worldwide-rs.com/File.ashx? $\mathrm{m}=3 \&$ path=Root/Documents/Brochures/WRS_Marine_Crew_Management_C.pdf

Zeymarine (2021). GLOBAL COVID 19 VACCINES SITUATION FOR SHIP CREW. https://zeymarine.com/global-covid-19-vaccines-situation-for-ship-crew/

\section{Figures}

Page $15 / 18$ 


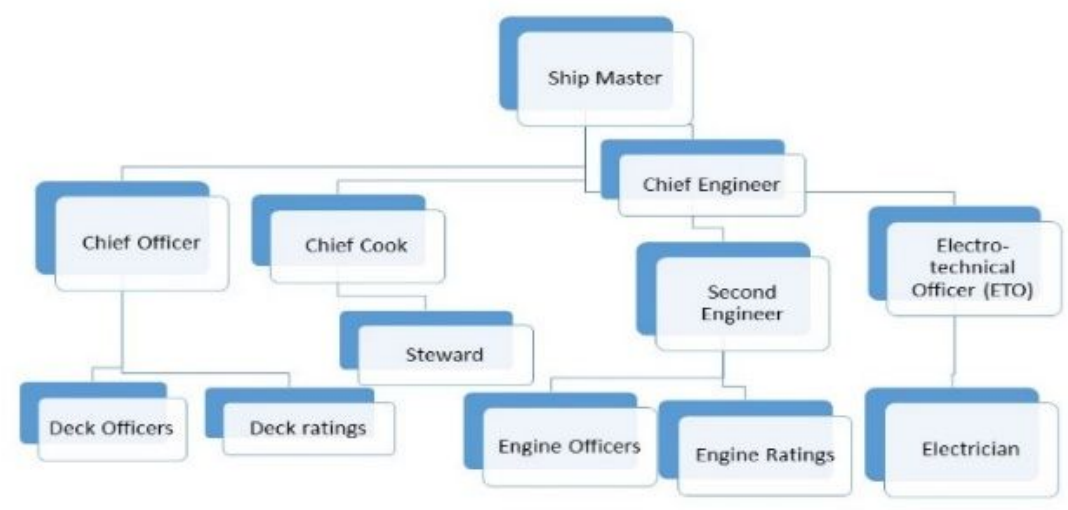

Figure 1

Ship manning structure per minimum manning requirement based on J. Toepfer (2016) description

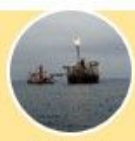

Stage 1: (Jan - Mar; Aug - Oct 2020)

covered a period of site attendances in the early days of covid-19 within offshore Ghana Jubilee oil and gas field that largely occurred between the months of January to March 2020, and August to October 2020.

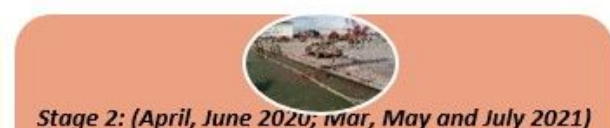

(April, June 202u, Mar, May and July 2021)

covered a shorter period of three days to a week duration during site attendances that observed the operational interfaces of marine survey practitioners

in the discharge of duty aboard various vessels. This

phase of the study focused on port locations of

Takoradi and Tema of Ghana, the port of Abidjan in Ivory Coast, the offshore ABO field of Nigeria and

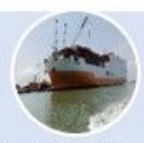

Stage 3: (Feb - May 2021)

which covers a period of online surveys, interviews with the seafaring and marine professionals in Africa's maritime industry concerning any concerns they have amid the pandemic.

\section{Figure 2}

Study Structure

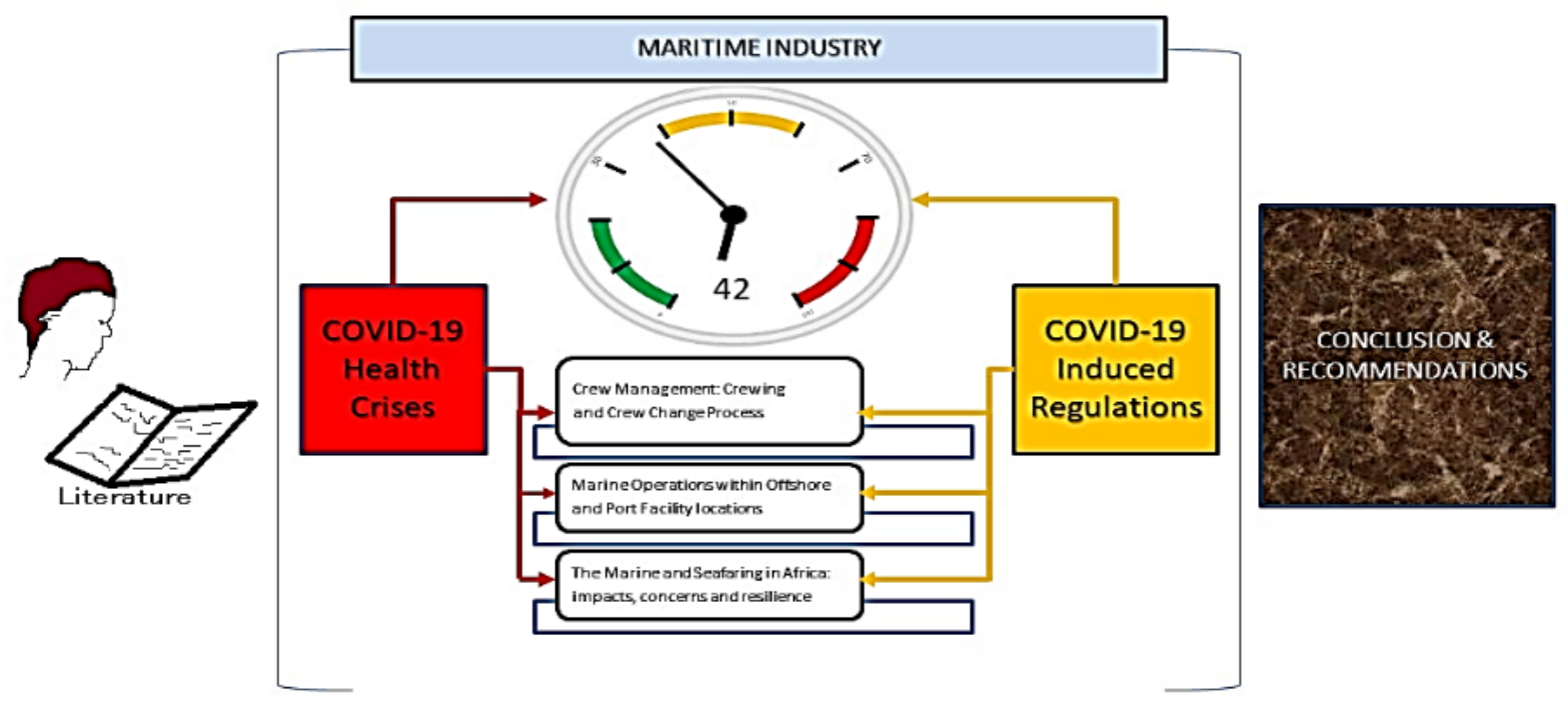

$7 / 21 / 2021$

Figure 3 
Total $=499$

Pointage Rating per Experience: 399

\begin{tabular}{|c|c|c|}
\hline 35 & Ship Officers & 8.77 \\
\hline 81 & Ship Ratings & 20.3 \\
\hline 105 & Offshore project Crew & 26.32 \\
\hline 48 & $\begin{array}{l}\text { Other Marine } \\
\text { Professionals }\end{array}$ & 12.0 \\
\hline 85 & Engine Officers & 21.3 \\
\hline 45 & Engine Ratings & 11.28 \\
\hline
\end{tabular}

Figure 4

Ranks per against marine experience and occupation in evaluating the responses of Respondents

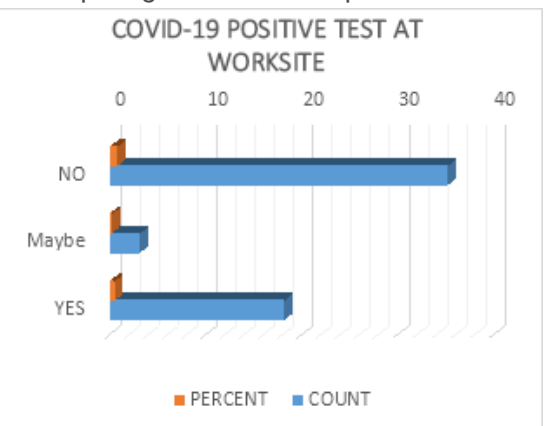

Figure 5

Respondent responses of whether there have been a Covid-19 positive test ever at their worksite

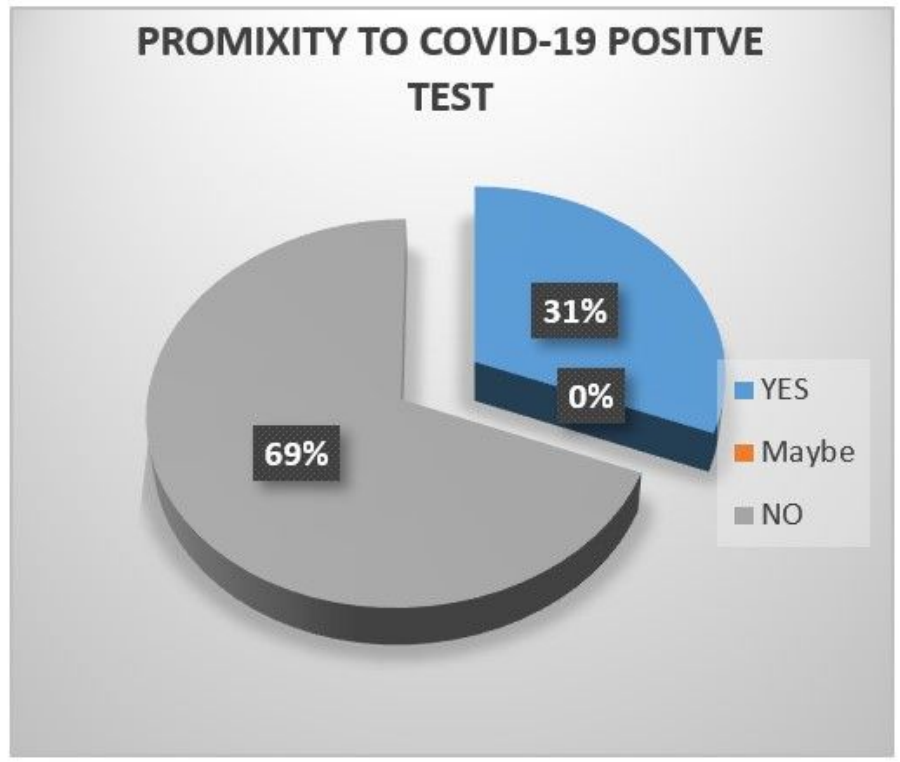

Figure 6

Respondent response if they or any close associate have had positive covid-19 test 


\section{Supplementary Files}

This is a list of supplementary files associated with this preprint. Click to download.

- Appendices.docx 